\title{
Use of SWAT to Compute Groundwater Table DePth and Streamflow in the Muscatatuck River Watershed
}

\author{
G. G. Vazquez-Amábile, B. A. Engel
}

\begin{abstract}
Groundwater table depth oscillation over time is an important issue for planning drainage systems in rural watersheds. Its proximity to the soil surface impacts soil properties, crop development, and agricultural chemical transport. Even though hydrologic models are valuable tools for simulating and predicting changes in water dynamics, groundwater table depth is usually difficult to predict. The Soil Water Assessment Tool (SWAT) is a continuous and distributed hydrologic model created to simulate the effect of land management practices on water, chemicals, and sediment movement for large watersheds. However, groundwater table depth is not computed by the model. A procedure to compute perched groundwater table depth using SWAT outputs is proposed, based on the theory used by DRAINMOD, in order to expand SWAT's capabilities. SWAT was calibrated and validated for streamflow for three watersheds, and for groundwater table depth for three soils, at sites located within the Muscatatuck River basin in southeast Indiana. The Nash-Sutcliffe model efficiency $\left(R_{N}^{2}\right)$ for monthly streamflow was 0.49, 0.61, and 0.81 for the three watersheds for the validation period (1995-2002). SWAT-predicted groundwater table depths provided $R^{2} N$ values of 0.61, 0.36, and 0.40 for the three soils in the calibration period (1992-1994) and $0.10,-0.51$, and 0.38 for the validation period (1995-1996). Even though the model performance for predicting groundwater table depth was not as good as for streamflow, SWAT predictions resembled the seasonal variation of the groundwater table with correlation coefficients $(r)$ of 0.68, 0.67, and 0.45 for the three wells during the validation period.
\end{abstract}

Keywords. DRAINMOD, Groundwater table depth, Streamflow, SWAT.

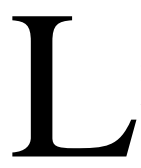
arge precipitation amounts not only cause excess flow in streams but also cause increases in soil water content, as well as rising groundwater tables, in areas not adjacent to rivers or streams. These effects are especially important on flat watersheds, where the stream network is not always well defined and water excesses are not rapidly removed by runoff. In rural watersheds, these effects may produce immediate damage. In these areas, groundwater table rises can decrease the total productivity of the watershed by reducing the farming area, affecting the development of the crops, and delaying or stopping field work (tillage, planting, and harvest), and they can degrade the soil properties for the next crop season (Pivot et al., 2002). In the long run, groundwater table rises may bring about soil salinization, depending on the groundwater quality.

At the watershed scale, two-dimensional hydrologic models are powerful tools that make it possible to gather geographic, soil, climatic, land use, and remote sensing data to be analyzed as a whole, in space and time dimensions. Logically, hydrologic models generally focus on the quantification of the variation in water quantity and quality in the stream network of the watershed. They largely represent the hydrologic cycle in terms of flow and storage (Haan et al., 1994).

Article was submitted for review in July 2004; approved for publication by the Soil \& Water Division of ASAE in May 2005.

The authors are Gabriel G. Vazquez-Amábile, PhD Student, and Bernard A. Engel, ASAE Member Engineer, Professor, Department of Agricultural and Biological Engineering, Purdue University, West Lafayette, Indiana. Corresponding author: Bernard A. Engel, ABE Bldg., 225 S. University St., Purdue University, West Lafayette, IN 47906-2093, phone: 765-494-1198; fax: 765-496-1115; e-mail: engelb@ purdue.edu.
The most common hydrologic model output variables are total runoff, peak discharge, and the hydrograph at the main outlet or at any point on the stream network. Other models that focus on erosion, such as EPIC (Williams et al., 1984), WEPP (Ascough et al., 1997), and SWRRB (Williams et al., 1985), and water quality, such as HSPF (Bicknell et al., 1996), QUAL2E (Brown and Barnwell, 1987), CREAMS (Knisel, 1980), and GLEAMS (Leonard et al., 1987), also calculate output variables such as sediment load and nutrient and pesticide concentration at different points on the stream network.

Thus, hydrologic models, especially at the river basin scale, are typically focused on water bodies rather than the land areas. The area of the watershed is considered the place where precipitation either runs off or infiltrates. Whether the model is lumped or distributed, event or continuous, stochastic or deterministic, the catchment area constitutes the mesh that receives precipitation and retains or delays the water on its way to the streams. For example, in SWAT (Arnold et al., 1998), a continuous model, soil water content and water table height, among many other variables, are simulated, but as intermediate steps to determine water quantity and quality at the main outlet or at other points on the stream network.

This kind of analysis is appropriate when the focus is the quantity and quality of the water that flows through the streams of the watershed. Engineers who design flood control structures and researchers and technicians who deal with environmental pollution carry out their analysis from this perspective. However, if watershed soil moisture, groundwater table depth, and suitability for farm activities throughout the year are of interest, perhaps new types of analysis are needed to generate appropriate outputs. In both cases, the 
simulated processes (infiltration, runoff, etc.) will be the same, but the analysis and the output information will be different. Thus, it may not be necessary to develop a new model, but only modify an existing hydrologic model, in order to extract additional information.

The objective of the work presented here was to extend the SWAT model to compute groundwater table depth, which is a variable of interest when rural watersheds are analyzed at the river basin scale. Thus, the main goal of this study was to incorporate some knowledge from DRAINMOD (Skaggs, 1980) into SWAT in order to expand its capabilities, while respecting the essence of the model. The intention of computing groundwater table depth is not to change the soil water balance of the SWAT model, but to provide an additional variable of interest.

In this study, SWAT outputs were used to compute groundwater table depth for three soil series in southeast Indiana based on the theory used by DRAINMOD. Primarily, SWAT was calibrated and validated for streamflow on three watersheds within the Muscatatuck River watershed, located in southeast Indiana. Then, SWAT was tested to compute water table depth on a smaller watershed in the Muscatatuck Wildlife Refuge.

The comparison between the performance of SWAT and DRAINMOD was not a goal of this work; rather, these models are complementary. DRAINMOD is a one-dimensional field-scale continuous model designed to compute shallow aquifer table depth and the effect of tile drainage systems in the soil water balance and crop yield. SWAT is a two-dimensional continuous hydrologic model that works at watershed and/or river basin scales. Even though SWAT has incorporated tile drains as a management practice, it does not compute groundwater table depth, and the impact of that practice may only be analyzed through base flow changes. DRAINMOD can be used to analyze tile drain designs at the field level, but it cannot be used for watershed analysis. Both models have different approaches to compute soil water balances: DRAINMOD uses the Green-Ampt equation using hourly precipitation and soil retention curves; SWAT computes infiltration either at saturated flow using the $\mathrm{CN}$ method and daily precipitation, or using the Green-Ampt equation and hourly precipitation without soil retention curves. In this study, infiltration was computed by SWAT using the $\mathrm{CN}$ method and daily precipitation.

Groundwater table depth is a variable of interest for basin-scale studies, and SWAT may be an efficient tool to compute it. The main advantage of modeling groundwater table depth with SWAT is that SWAT does not necessarily require sub-daily precipitation data, does not require the retention curve for the soils, and can model more than one soil simultaneously in different subbasins in large watersheds, comparing scenarios and generating thematic maps.

\section{LITERATURE REVIEW}

A river basin model is more appropriate than a small catchment model for regional studies of hydrologic variables. Water quality simulation is important in order to study the long-term effects of floods and management on nonpointsource (NPS) pollution. An example of this is the great flood of 1993, caused by several precipitation events, and the large amount of nitrate transported from farm fields through the Mississippi River to the Gulf of Mexico (Changnon, 1996; Miller and Miller, 2000). In addition, in the long run, floods may also cause changes in chemical soil properties, such as soil salinity produced by saline groundwater table rises. To compute long-term effects, it is also necessary that the model be continuous, because the effect of gradual changes on water dynamics, such as groundwater table oscillation, cannot be analyzed using event models.

There are various continuous and distributed hydrologic models that work at different scales. At the catchment scale, TOPMODEL (Ambroise et al., 1996), for example, is a distributed hydrologic model that is recommended for watersheds up to 5,000 ha in area. It simulates groundwater table depth at any location and computes runoff as infiltration excess calculated by the exponential Green-Ampt equation (Beven, 1984). ANSWERS-2000 (Dillaha et al., 1998) is a distributed, physically based, continuous model for farm- or watershed-scale applications up to 3000 ha. It has been frequently used to evaluate effectiveness of agricultural and urban BMPs in reducing sediment and nutrient delivery.

Another distributed hydrologic model is MIKE-SHE (European Hydrologic System), developed by three European organizations (Refshaard et al., 1995). It is a distributed, physically based, hydrological integrated and water quality modeling system. MIKE-SHE is a powerful system, but it is not public domain, and the code is not open to be modified. The main shortcoming of MIKE-SHE is that in many cases, some parameters are not available, which makes it difficult to set up the model. It works at the catchment scale, but it can be used in bigger watersheds, although it is limited by computer memory.

SWAT has been chosen for this project because it can be used in large watersheds up to river basin scale. It is a public domain model, user friendly, has open code, allows generation of several scenarios, and requires inputs that can be easily gathered for most watersheds in the U.S.

SWAT is a daily step, comprehensive, distributed and continuous model. SWAT is a river basin or watershed scale model and it was created to predict the impact of land management practices on water, sediment, and agricultural chemical yields in large, complex watersheds with varying soils, land use, and management conditions over long periods of time. It calculates many processes of the hydrologic cycle based on specific information about weather, soil properties, topography, vegetation, and land management practices occurring in the watershed. In its GIS version, AVSWAT2000 (Di Luzio et al., 2001), some inputs, such as soils, land use, elevation, streams, outlets, and gauges are introduced as ArcView files (shapes and grids). The model can compute numerous processes with regard to water, sediment, nutrient, and pesticide loadings throughout large and complex watersheds. SWAT computes soil temperature, snowfall, and snowmelt, and all weather variables can also be generated from average monthly values for simulations that do not need measured data. On rainy days, or under irrigation, surface runoff is computed along with canopy storage, infiltration, peak rate, stream transmission losses, soil erosion, sediment yield, and nutrient and pesticide yields. Furthermore, SWAT computes on a daily basis, for each HRU in every subbasin, the soil water balance, groundwater flow, lateral flow and channel routing (main and tributary), evapotranspiration, crop growth and nutrient uptake, pond, wetland balances, soil pesticide degradation, and in-stream transformation of nutrients and pesticides. Other subroutines, such as irrigation, tillage, fertilization, pesticide application, and tile drainage, are computed based on user settings. 
SWAT computes runoff infiltration using the $\mathrm{CN}$ method at a daily step or using the Green-Ampt method when sub-daily precipitation data are available. The redistribution component of SWAT uses a storage routing technique to predict flow through each soil layer in the root zone. Downward flow or percolation occurs when a soil layer exceeds field capacity and the layer below is not saturated. Flow rate is determined by the saturated hydraulic conductivity of the soil layer. No redistribution is allowed if the soil layer temperature is equal to $0^{\circ} \mathrm{C}$ or below. SWAT directly simulates only saturated flow between layers and assumes that water content is uniformly distributed within a given layer. Unsaturated flow between layers is indirectly simulated by depth distribution of plant water uptake, by depth distribution of soil water evaporation, and by the upward flow from the shallow aquifer to the unsaturated soil layers. Thus, upward flow in SWAT is not referred to as water table depth, as in DRAINMOD. The theoretical details are explained in detail in the SWAT documentation provided by the authors in Neitsch et al. (2001).

In watershed studies, runoff is usually the main concern, and SWAT has been evaluated in different regions, showing good performance when predicting surface and subsurface runoff (Saleh et al., 2000; Spruill et al., 2000; Arnold and Allen, 1996). However, the seasonal variation of groundwater table depth is also an important variable in many situations, especially when the shallow aquifer is a perched water table that oscillates between the soil surface and the soil bottom layer. SWAT calculates on a daily basis the soil water balance and the water stored both in a shallow and a deeper aquifer.

For SWAT, the shallow aquifer works like a reservoir, always located somewhere below the soil profile, and separated by a vadose zone, that receives water percolated from the lowest soil layer, which is conducted under the surface and discharged either into the nearest stream or into a deeper aquifer (fig. 1). Thus, the shallow aquifer plays a key role contributing stream baseflow and moisture to the overlaying soil layers by capillary pressure or by direct absorption by the plant roots. In SWAT, this process of upward movement from the shallow aquifer is termed "revap" to avoid confusion with soil evaporation and transpiration.

This definition of shallow aquifer works well when groundwater table depth oscillation is not considered a variable of interest. However, the shallow aquifer is not always located exactly below the soil profile, and it works like a perched water table presenting seasonal oscillation. SWAT considers that situation and uses a kinematic storage model to compute the "lateral flow," which simulates subsurface flow above impermeable layers within the soil profile.

Therefore, stream baseflow in SWAT is composed of groundwater flow from the shallow aquifer located below the soil and by lateral flow from the soil's saturated zone (fig. 1). Thus, in poorly drained soils, the water excess that does not drain vertically travels to the stream by lateral flow, and the water that drains vertically and leaves the soil (deep seepage) is stored in the shallow aquifer and released to streams by "groundwater flow." Furthermore, SWAT computes a variable termed "groundwater table height," which expresses the thickness of the shallow aquifer in terms of depth of water stored, but it is not referenced to any datum or distance from the soil surface. Therefore, this variable must not be confused with groundwater table depth. Nevertheless, even though SWAT does not compute the water table depth that oscillates within or below the soil profile, it computes all the variables necessary to calculate it. The purpose of this study was to identify a way to compute the depth of the saturated zone without using additional model inputs.

\section{Methodology StUdy AreA}

The study area was the Muscatatuck River watershed, defined by the USGS as 8-digit HUA No. 05120207. It has an area of 295,221 ha and is located in southeast Indiana (fig. 2)

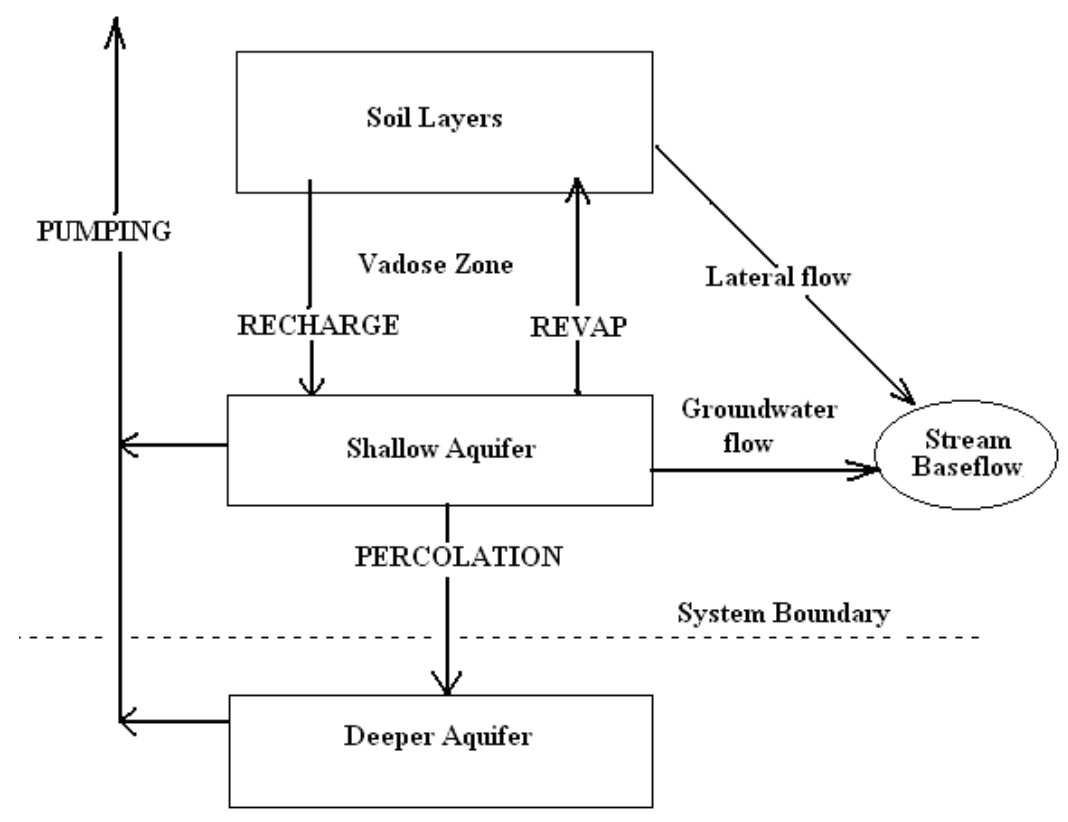

Figure 1. Main groundwater processes in SWAT. 


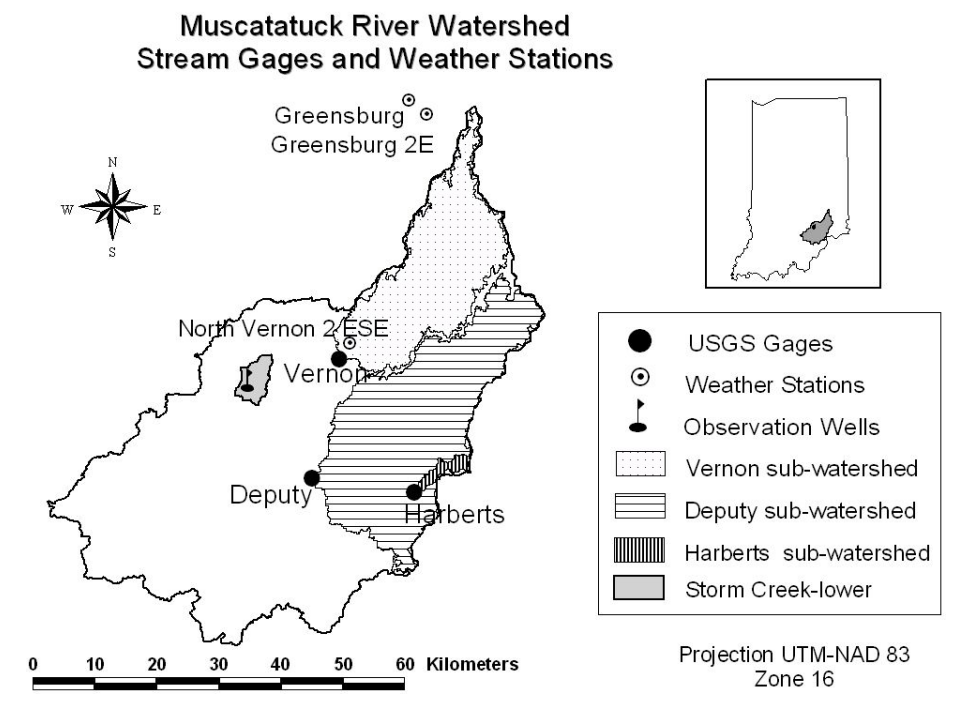

Figure 2. Weather stations and USGS gauges for the Muscatatuck River watershed.

in Decatur, Jennings, Ripley, Jefferson, Scott, and Jackson counties. The SWAT model calibration and validation for streamflow was carried out using data recorded at the three USGS stream gauges of the watershed, located at Vernon, Deputy, and Harberts Creek. Groundwater table depth calibration and validation were conducted using data from three observation wells located in the Storm Creek lower watershed (14-digit HUA No. 05120207080040).

\section{Weather, Streamflow, and Groundwater Table Data}

Daily weather data for precipitation and maximum and minimum temperature were obtained from the records of the weather stations listed in table 1 for the period 1976-2002. Observed daily streamflow datasets used in the SWAT calibration and validation were downloaded from the USGS website (USGS, 2003a). The data for the period 1976-2002 were recorded at USGS gauges 03369500 (Vernon), 03366500 (Deputy), and 03366200 (Harberts Creek near Madison).

Groundwater table data recorded by Jenkinson (1998) during the period 1992-1996 were used for groundwater table depth calibration and validation. Groundwater table was measured at three observation wells located in three soil series (Avonburg, Rossmoyne, and Cobbsfork) at the Muscatatuck Wildlife Refuge in the Storm Creek lower watershed (14-digit HUA No. 05120207080040), as shown in figure 2. The observation wells were made from a $3.0 \mathrm{~m}$ length of schedule 40 PVC plastic pipe that had an inside diameter of $7.62 \mathrm{~cm}$. Two slots $0.32 \mathrm{~cm}$ wide with a chord length of $6.5 \mathrm{~cm}$ were located on opposite sides at $5 \mathrm{~cm}$ intervals along the length of the pipe for a distance of $2.5 \mathrm{~m}$. The pipes were installed in the soil by augering a hole using an $8.9 \mathrm{~cm}$ diameter auger bit to a depth $2.5 \mathrm{~m}$ (Jenkinson, 1998).

\section{SoIL Data}

Soil data from the State Soil Geographic Database for the Conterminous U.S. (STATSGO; approximate scale 1:250,000) were used when the 8-digit HUA area was analyzed for streamflow calibration and validation, because more detailed information from the Soil Survey Geographic database (SSURGO) was not available for the six counties included in the watershed. SSURGO data were available for Jennings and Jackson counties and were used for the groundwater table depth calibration and validation at the Muscatatuck Wildlife Refuge, located in the 14-digit HUA Storm Creek lower watershed.

Prior to running SWAT for groundwater analysis, the SSURGO file (usersoil.dbf) for SWAT for Indiana was checked and updated using the soil information for Jackson (NRCS, 1990) and Jennings (NRCS, 1976) counties. Two layers were added for the Avonburg series, and one layer was added for the Cobbsfork and Rossmoyne series. The soil input data are presented in tables 2 through 4 .

\section{Land Use, Elevation, and Hydrographic Data}

Land use data used for this research were obtained from the EROS 1998 dataset developed by the Earth Resources Observation Systems (EROS) Data Center (EDC) at Sioux Falls, South Dakota, using Landsat TM data, acquired between the years 1988 and 1994. Land use distribution of the major classes for the Muscatatuck River watershed (8-digit HUA) was $23.8 \%$ agriculture, $36.2 \%$ pasture, $34.9 \%$ forest, $2.0 \%$ wetlands, $2.6 \%$ urban and transitional, and $0.5 \%$ water bodies.

Elevation data used in this project were obtained from the National Elevation Dataset (NED-NAD 83) DEM with a resolution of 1 arc-sec (approximately $30 \mathrm{~m}$ ), developed by USGS. The streams shape file used in the "burn-in" of the

Table 1. Weather stations used in SWAT simulations.

\begin{tabular}{lccccc}
\hline Station Name & U.S. Weather Station & Elevation & Period & County \\
\hline Greensburg 2E & 123547 & $39^{\circ} 20^{\prime} \mathrm{N}, 85^{\circ} 27^{\prime} \mathrm{W}$ & 299 & $1976-1985$ & Decatur \\
Greensburg & 123547 & $39^{\circ} 21^{\prime} \mathrm{N}, 85^{\circ} 29^{\prime} \mathrm{W}$ & 285 & $1985-2002$ & Decatur \\
North Vernon 2 ESE & 126435 & $39^{\circ} 00^{\prime} \mathrm{N}, 85^{\circ} 36^{\prime} \mathrm{W}$ & 225.6 & $1976-2002$ & Jennings \\
\hline
\end{tabular}


Table 2. Avonburg soil series input data by layer.

\begin{tabular}{|c|c|c|c|c|c|c|c|c|c|}
\hline Layer & $\begin{array}{c}\text { Cumulative } \\
\text { Depth } \\
\text { (mm) }\end{array}$ & $\begin{array}{l}\text { Clay } \\
(\%)\end{array}$ & $\begin{array}{l}\text { Silt } \\
(\%)\end{array}$ & $\begin{array}{c}\text { Sand } \\
(\%)\end{array}$ & $\begin{array}{c}\mathrm{AWC} \\
\left(\mathrm{mm} \mathrm{mm}^{-1}\right)\end{array}$ & $\begin{array}{c}\text { WP } \\
\left(\mathrm{mm} \mathrm{mm}^{-1}\right)\end{array}$ & $\begin{array}{c}\text { Bulk } \\
\text { Density } \\
\left(\mathrm{g} \mathrm{cm}^{-3}\right)\end{array}$ & $\begin{array}{l}\text { Porosity } \\
\left(\mathrm{mm} \mathrm{mm}^{-1}\right)\end{array}$ & $\begin{array}{c}\text { Drainage } \\
\text { Porosity } \\
\left(\mathrm{mm} \mathrm{mm}^{-1}\right)\end{array}$ \\
\hline 1 & 450 & 16.1 & 67.8 & 16.1 & 0.22 & 0.09 & 1.38 & 0.479 & 0.170 \\
\hline 2 & 1070 & 28.7 & 62 & 9.3 & 0.14 & 0.18 & 1.55 & 0.415 & 0.097 \\
\hline 3 & 1420 & 22.8 & 61.1 & 16.1 & 0.14 & 0.15 & 1.69 & 0.362 & 0.068 \\
\hline 4 & 2000 & 19 & 55.3 & 25.7 & 0.18 & 0.13 & 1.7 & 0.358 & 0.049 \\
\hline 5 & 2440 & 26.7 & 46.4 & 26.9 & 0.13 & 0.18 & 1.73 & 0.347 & 0.032 \\
\hline 6 & 2870 & 35.2 & 30.7 & 34.1 & 0.14 & 0.23 & 1.61 & 0.392 & 0.026 \\
\hline
\end{tabular}

Table 3. Cobbsfork soil series input data by layer.

\begin{tabular}{|c|c|c|c|c|c|c|c|c|c|}
\hline Layer & $\begin{array}{c}\text { Cumulative } \\
\text { Depth } \\
\text { (mm) }\end{array}$ & $\begin{array}{l}\text { Clay } \\
(\%)\end{array}$ & $\begin{array}{l}\text { Silt } \\
(\%)\end{array}$ & $\begin{array}{c}\text { Sand } \\
(\%)\end{array}$ & $\begin{array}{c}\mathrm{AWC} \\
\left(\mathrm{mm} \mathrm{mm}^{-1}\right)\end{array}$ & $\begin{array}{c}\mathrm{WP} \\
\left(\mathrm{mm} \mathrm{mm}^{-1}\right)\end{array}$ & $\begin{array}{c}\text { Bulk } \\
\text { Density } \\
\left(\mathrm{g} \mathrm{cm}^{-3}\right)\end{array}$ & $\begin{array}{l}\text { Porosity } \\
\left(\mathrm{mm} \mathrm{mm}^{-1}\right)\end{array}$ & $\begin{array}{c}\text { Drainage } \\
\text { Porosity } \\
\left(\mathrm{mm} \mathrm{mm}^{-1}\right)\end{array}$ \\
\hline 1 & 280 & 16.5 & 65.9 & 17.6 & 0.20 & 0.096 & 1.45 & 0.453 & 0.157 \\
\hline 2 & 560 & 18.0 & 65.0 & 17.0 & 0.19 & 0.112 & 1.56 & 0.411 & 0.109 \\
\hline 3 & 1070 & 25.2 & 59.0 & 15.8 & 0.17 & 0.164 & 1.63 & 0.385 & 0.051 \\
\hline 4 & 1930 & 23.9 & 54.7 & 21.4 & 0.15 & 0.164 & 1.72 & 0.351 & 0.037 \\
\hline 5 & 2590 & 29.3 & 48.7 & 22.0 & 0.09 & 0.205 & 1.75 & 0.340 & 0.045 \\
\hline
\end{tabular}

Table 4. Rossmoyne soil series input data by layer.

\begin{tabular}{cccccccccc}
\hline Layer & $\begin{array}{c}\text { Cumulative } \\
\text { Depth } \\
(\mathrm{mm})\end{array}$ & $\begin{array}{c}\text { Clay } \\
(\%)\end{array}$ & $\begin{array}{c}\text { Silt } \\
(\%)\end{array}$ & $\begin{array}{c}\text { Sand } \\
(\%)\end{array}$ & $\begin{array}{c}\text { AWC } \\
\left(\mathrm{mm} \mathrm{mm}^{-1}\right)\end{array}$ & $\begin{array}{c}\text { WP } \\
\left(\mathrm{mm} \mathrm{mm}^{-1}\right)\end{array}$ & $\begin{array}{c}\text { Bulk } \\
\text { Density } \\
\left(\mathrm{g} \mathrm{cm}^{-3}\right)\end{array}$ & $\begin{array}{c}\text { Porosity } \\
\left(\mathrm{mm} \mathrm{mm}^{-1}\right)\end{array}$ & $\begin{array}{c}\text { Drainage } \\
\text { Porosity } \\
\left(\mathrm{mm} \mathrm{mm}^{-1}\right)\end{array}$ \\
\hline 1 & 320 & 11.45 & 71.4 & 17.5 & 0.23 & 0.060 & 1.32 & 0.502 & 0.211 \\
2 & 570 & 12 & 72.2 & 15.8 & 0.25 & 0.074 & 1.55 & 0.415 & 0.091 \\
3 & 940 & 26.6 & 63.5 & 9.90 & 0.11 & 0.162 & 1.52 & 0.426 & 0.155 \\
4 & 1200 & 24.54 & 63.46 & 12.0 & 0.14 & 0.159 & 1.62 & 0.389 & 0.090 \\
5 & 2400 & 20.4 & 51.1 & 28.5 & 0.16 & 0.143 & 1.75 & 0.340 & 0.037 \\
\hline
\end{tabular}

DEM, in the stream definition process, was a subset of the National Hydrography Dataset (NHD) for Indiana, prepared by USGS.

\section{SWAT GROUNDWATER INPUTS}

Prior to determining groundwater inputs, a sensitivity analysis was performed to quantify the impact of input changes on the simulated streamflow. Baseflow days, groundwater delay, and specific yield were adjusted, and the remaining groundwater inputs were set as model default values.

Baseflow days were computed using the RECESS model (USGS, 2003b), a program developed by Rutledge (1993) to determine the recession index and the master recession curve from daily streamflow records.

Groundwater delay, expressed in days, is the time that the water released by the soil bottom layer travels until reaching the shallow aquifer. For this study, groundwater delay was set at zero days, assuming there was no vadose zone between the lower limit of the soil bottom layer and the shallow aquifer, which fluctuated from the surface to $2.5 \mathrm{~m}$ during the year.

The default value for the shallow aquifer specific yield (0.003) was replaced by 0.18 , corresponding to the average specific yield for silt (Johnson, 1967), according to the high proportion of that material in the subsoil. The remaining inputs were set as model default values.

\section{Calculating Groundwater Table Depth from SoIl MOISTURE IN SWAT}

SWAT calculates the daily soil water balance. Every day, the model updates the amount of water stored in every soil layer for every hydrologic response unit (HRU). However, soil water content is an output variable for the soil profile as a whole, not for every layer. For this project, a modification of the code was provided by the authors of SWAT in order to provide soil water content by layer for every HRU in an additional output file. Using this special output file, it was possible to convert soil moisture into groundwater table level following the theory used by DRAINMOD (Skaggs, 1980) without modifying the main code of the SWAT model and without additional inputs.

This procedure is based on the relationship between water table depth and drainage volume, which is the effective air volume above the water table. This relationship can be calculated for every soil from the drainage volume of every layer, building the curve that depicts that relationship. In DRAINMOD, this relationship is used to determine the water table fall or rise when a given amount of water is removed from or added to the soil profile. Drainage volume can be computed from the soil water characteristics for each soil horizon. However, when this information is not available, drainage volume can be calculated from the estimated drainage porosity of each soil layer (Skaggs, 1980). The latter approach is useful in regional studies where detailed soil information is not available, and it was evaluated in this study because of its compatibility with the SWAT soil input data.

The drainage volume is the void space that holds water between field capacity and saturation. It can be understood as the total volume of voids filled with air at field capacity. The volume of water stored in the void space, termed "drainable volume" here, always drains by gravity. Even though the terms "drainage volume" and "drainable volume" are similar, and therefore may be confusing, they were used here as defined for DRAINMOD in order to maintain the same terminology. Drainage volume is the volume of air held 
in macropores, and drainable water is the volume of water held in macropores.

If a completely saturated soil is left to drain under the force of gravity, the volume that drains (drainable volume) is equal to the drainage volume. That drainage volume, expressed as a fraction of the bulk volume, is termed specific yield $(S y)$ or drainage porosity (Charbeneau, 2000). It is also important to keep in mind that soils are rarely fully saturated because of entrapped air. Thus, total saturation is usually around $90 \%$ or $95 \%$ of the soil porosity (Skaggs, 1980).

The drainage volume is related to groundwater table depth. Below the groundwater table, the drainage volume is equal to zero because there is no air in the macropores. Thus, if the water table is lowered by an amount of $\Delta H(\mathrm{~mm})$, the water drained by the soil, in terms of water depth $(\mathrm{mm})$, will be equal to the drainage porosity $(S y)$ multiplied by $\Delta H$ :

$$
\text { Drainage volume }(\mathrm{mm})=S y \times \Delta H
$$

Below the groundwater table, the soil is saturated, and all the voids are filled with water. The saturation upper limit is then calculated as equal to the soil porosity, and the soil porosity $(\%)$ is calculated as:

$$
\text { Porosity } \begin{aligned}
(\%) & =1-\left(\frac{\text { Bulk density }}{\text { Particle density }}\right) \times 100 \\
& =1-\left(\frac{\text { Bulk density }}{2.65}\right) \times 100
\end{aligned}
$$

Thus, the drainage porosity for each layer is given by the relationship:

$$
\text { Drainage porosity }=\text { Porosity }- \text { Field capacity }
$$

Using the variables defined in SWAT, field capacity will be equal to the available water content plus the wilting point. Thus, equation 3 can be written as:

$$
\text { Drainage porosity }=\text { Porosity }-\mathrm{AWC}-\mathrm{WP}
$$

where AWC is soil available water content, which is a model soil input, also termed the water retention difference (WRD) by NRCS, equivalent to the amount of water stored between wilting point and field capacity, and WP is the wilting point, that is, the fraction of micropores that hold water at high pressures, which is not available to the crops. SWAT estimates WP as:

$$
\mathrm{WP}=0.4 \times \text { Clay }(\%) \times\left(\frac{\text { Bulk density }}{100}\right)
$$

Drainage porosity was initially calculated for each layer of the three soils, and drainage volume $(\mathrm{mm})$ was computed daily from the soil water stored for every layer (eq. 6a) and for the soil profile (eq. 6b):

$$
\begin{gathered}
\text { Layer drainage volume }(\mathrm{mm}) \\
=\text { Drainage porosity } \times \text { Layer depth }(\mathrm{mm})
\end{gathered}
$$

Total drainage volume $(\mathrm{mm})$

$$
=\Sigma \text { Layer drainage volume }
$$

Therefore, "total drainage volume" is the volume of voids filled with air in the soil profile at field capacity (FC). The total drainage volume changes depending on the degree of saturation of the soil above FC. If the soil water content is at $100 \%$ of AWC, then the "actual" drainage volume is equal to the soil's total drainage volume at FC. However, if the soil is above $100 \%$ AWC, then the "actual" drainage volume will be smaller than the soil's total drainage volume.

The relationship of total drainage volume and water table depth was calculated using the layer drainage volume ( $\mathrm{mm}$ ) and the layer depth. Each layer has a special relationship, which is defined by the specific yield. This relationship can be simplified as a linear function where the specific yield, or drainage porosity, is the slope (Skaggs, 1980). A clear example for a hypothetical two-layer soil is presented in figure 3, adapted from the DRAINMOD user manual (Skaggs, 1980). The horizontal axis represents the water table depth, and the soil depth, and the vertical axis represents the total drainage volume. In the plot, the curve for each layer and the composite curve for the soil profile can be observed. The top layer $(0-30 \mathrm{~cm})$ has a drainable porosity of 0.12 , and the bottom layer $(30-120 \mathrm{~cm})$ has a drainable porosity of 0.04 . The soil profile curve turns out to be a composite of the two layer curves and is built using the cumulative drainage porosity. For the top layer of the soil shown in figure 3, the relationship will be:

$$
\begin{aligned}
& \text { Drainage volume }_{(\text {top })}(\mathrm{cm}) \\
& \quad=0.12 \times \text { layer }_{(\text {top })} \text { depth }(\mathrm{cm}) \\
& =0.12 \times 30 \mathrm{~cm} \\
& =3.6 \mathrm{~cm}
\end{aligned}
$$

Therefore, the water table depth will be "at least" $30 \mathrm{~cm}$ when the top layer has a drainage volume of $3.6 \mathrm{~cm}$, which means that $100 \%$ of the drainage porosity is filled with air. For the bottom layer:

$$
\begin{aligned}
& \text { Drainage volume }_{(\text {bottom })}(\mathrm{cm}) \\
& =0.04 \times \text { layer }_{(\text {bottom })} \text { depth }(\mathrm{cm}) \\
& =0.04 \times 70 \mathrm{~cm} \\
& =2.8 \mathrm{~cm}
\end{aligned}
$$

The cumulative or total drainage volume at $100 \mathrm{~cm}$ depth will be the sum of the drainage volumes of both layers, which is $6.4 \mathrm{~cm}$, and represents the volume of air when the soil is at field capacity. If the points of cumulative drainage volume of each layer are joined, the cumulative curve for the soil profile is obtained. Thus, graphically, intercepting the curve for any drainage volume of soil profile, the groundwater table depth can be obtained (fig. 3).

The same procedure was followed to build the curves for the three soils series: Avonburg, Cobbsfork, and Rossmoyne. The curve for Avonburg is shown in figure 4. The graphical method is simple, but it becomes cumbersome when there is a large amount of data. In this study, there were 3650 daily data values, corresponding to the daily soil drainage volume values of a 10-year simulation for each soil of the watershed.

Analytically, groundwater table depth was determined as follows. First, using soil input data, the cumulative drainage volume of the soil was computed from top to bottom, and the intercept corresponding to the linear function of each layer was also calculated, as can be seen graphically in figure 4 . 


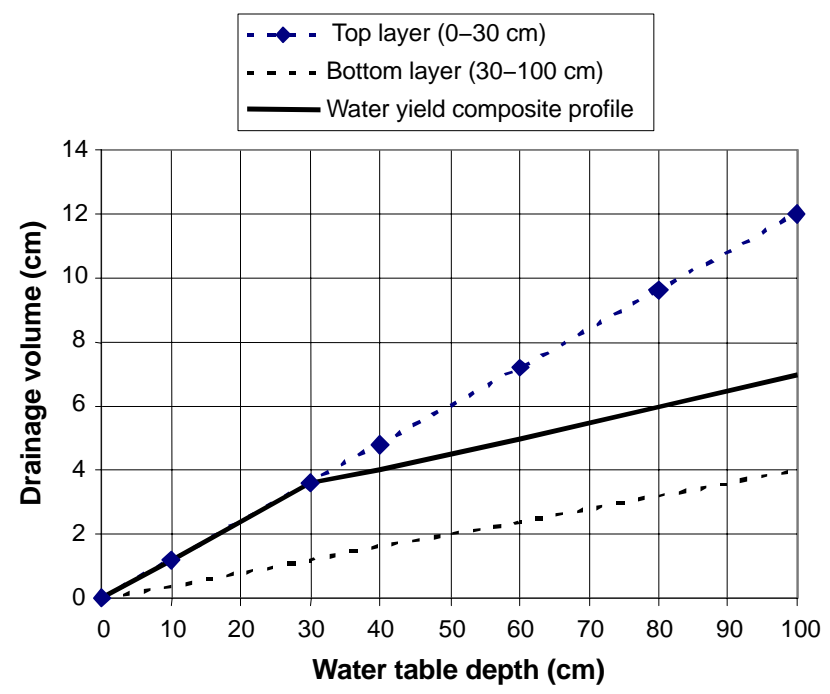

Figure 3. Layers and soil profile water yield curves (Skaggs, 1980).

Table 5 shows the results for the Avonburg series; the same procedure was followed for the other two soils. The intercept of each layer was computed as:

$$
\begin{aligned}
& \text { Intercept }_{\text {Layer }}=\text { Cumulative drainage volume } \\
& -\left(\text { Specific yield }_{\text {Layer }} \times \text { Cumulative depth }_{\text {Layer }}\right)
\end{aligned}
$$

Second, the total drainage volume of the soil profile was computed for the three soils for every day of the simulation using the output file. Using the daily values of soil water content for each layer, the amount of water stored above field capacity at the end of the day was computed, which can be termed either water excess or drainable water volume. Once the water excess is known, this amount is subtracted from total drainage volume in order to get the "actual" drainage volume, which is the pore space filled with air on a particular day. The actual drainage volume of each layer was summarized daily to obtain the daily actual drainage volume of the soil profile. This is the value used to graphically intercept the curve to obtain the daily groundwater table depth.

If the daily computed actual drainage volume of the soil profile was lower than the drainage volume of the first layer, then the water table depth was computed using the linear relationship of the first layer. If the actual drainage volume was higher than the drainage volume of the first layer and smaller than the cumulative drainage volume of the second layer, then the function corresponding to the second layer was used, and so on.

In brief, if the actual drainage volume of the soil profile is zero, then the water table depth is zero, indicating that the soil is completely saturated and the water table is at the surface or above. If the actual drainage volume of the soil profile is equal to the total drainage volume, then the water table is below the bottom layer. The curves for the Rossmoyne and Cobbsfork soils series were also computed, as shown in figure 4 for Avonburg (Vazquez-Amábile, 2004). These curves were used to compute the daily groundwater depth for each soil.

This approach allows estimating the relationship between water table depth and drainage volume, but it is important to point out its limitations. The curves computed for the three soils depict a simplified linear relationship between soil drainage volume and water table depth. The slope of that relationship is depicted by the drainage porosity, assuming that the soil is completely drained immediately above the water table. However, there is a transition zone, or capillary fringe, above the water table, which is at saturation near its base while its upper extent is near field capacity (Charbeneau, 2000). This transition zone above the water table is

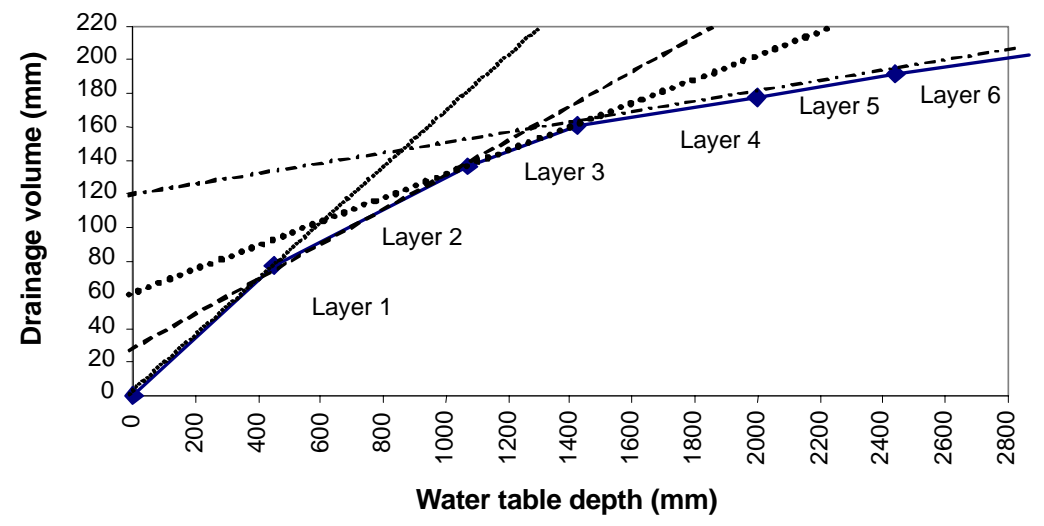

Figure 4. Soil profile water yield curve for the Avonburg series.

Table 5. Cumulative drainage volume and intercepts computed for the linear functions corresponding

\begin{tabular}{|c|c|c|c|c|c|c|c|c|c|}
\hline Layer & $\begin{array}{l}\text { Depth } \\
(\mathrm{mm})\end{array}$ & $\begin{array}{l}\text { Cumulative } \\
\text { Depth } \\
\text { (mm) }\end{array}$ & Porosity & $\begin{array}{c}\mathrm{AWC} \\
\left(\mathrm{mm} \mathrm{mm}^{-1}\right)\end{array}$ & $\begin{array}{c}\mathrm{WP} \\
\left(\mathrm{mm} \mathrm{mm}^{-1}\right)\end{array}$ & $\begin{array}{c}\text { Drainage } \\
\text { Porosity }(S y) \\
\left(\mathrm{mm} \mathrm{mm}^{-1}\right)\end{array}$ & $\begin{array}{l}\text { Drainage } \\
\text { Volume } \\
(\mathrm{mm})\end{array}$ & $\begin{array}{l}\text { Cumulative } \\
\text { Drainage Vol. } \\
(\mathrm{mm})\end{array}$ & Intercept \\
\hline 1 & 450 & 450 & 0.479 & 0.22 & 0.089 & 0.170 & 76.5 & 76.5 & 0.0 \\
\hline 2 & 620 & 1070 & 0.415 & 0.14 & 0.178 & 0.097 & 60.1 & 136.6 & 33.1 \\
\hline 3 & 350 & 1420 & 0.362 & 0.14 & 0.154 & 0.068 & 23.8 & 160.4 & 64.2 \\
\hline 4 & 580 & 2000 & 0.358 & 0.2 & 0.129 & 0.029 & 16.8 & 177.2 & 119.7 \\
\hline 5 & 440 & 2440 & 0.347 & 0.13 & 0.185 & 0.032 & 14.1 & 191.3 & 113.9 \\
\hline 6 & 430 & 2870 & 0.392 & 0.14 & 0.227 & 0.026 & 11.2 & 202.5 & 128.5 \\
\hline
\end{tabular}
to the segment of each layer in the cumulative soil curve for the Avonburg soil. 
more important in fine soils than in coarse soils, and it is not considered in this approach.

Therefore, for a given drainage volume, the curve estimated in this way will underpredict the water table depth. This underestimation will be more important as the silt and clay content increase. Conversely, for a given water table depth, the drainage volume will be overestimated. Since all three curves were based on this assumption, and the slope of every layer was given by the drainage porosity, the shape of the curves differs from that of the soil characteristic curves. This underestimation was partially corrected in the calibration process, as discussed later.

\section{Water Table MaXimum Depth}

The proposed procedure to compute groundwater table depth is based on the relationship between water table depth and soil drainage volume. Therefore, water table depth oscillation can only be computed from the soil surface down to the lower limit of the bottom layer defined in the soil input information. When the water table is located below the lower limit, its depth cannot be computed because there is no information to compute water stored out of the defined layers. In the case of the Avonburg soil, for example, the maximum observed depth of the shallow aquifer was $2.5 \mathrm{~m}$; therefore, the lower limit of the soil profile was defined at $2.8 \mathrm{~m}$.

As for the vadose zone, or unsaturated zone above the water table, its location depends on the depth of the water table. In the case of the Avonburg soil, for example, the vadose zone may be either above $2.8 \mathrm{~m}$ or below $2.8 \mathrm{~m}$, the lower limit of the bottom layer. If the water table is below $2.8 \mathrm{~m}$, then its depth cannot be computed. However, the shallow aquifer recharge rate can be calibrated using the groundwater input parameters. SWAT allows the user to define a vadose zone between the soil bottom layer and the shallow aquifer using the groundwater delay input, as discussed previously.

If the user knows that the shallow aquifer fluctuates from the surface down to a certain depth, it is important to define the soil input layers to that depth or below in order to provide enough soil information to compute water table oscillation. All soils of the watershed should be defined considering this point and individually calibrated, if possible. All soil units of the same series are assumed to be located in the same landscape position; therefore, the shallow aquifer should oscillate similarly in all units defined for that series. However, SWAT permits calibration of soil and groundwater parameters for a given soil for any HRU within any sub-basin. Thus, this approach allows prediction of shallow aquifer oscillation from the soil surface to the lower limit of the defined soil bottom layer. For that reason, the definition of soil inputs and the calibration of soil and groundwater input parameters are very important steps in the process of predicting this variable using SWAT.

\section{Results AND Discussion}

\section{Streamflow Calibration and Validation}

Streamflow calibration was completed using data recorded by USGS at three watershed stream gauges between 1980 and 1994. This process was conducted by comparing monthly and daily observed streamflow with monthly and daily water yield predicted by SWAT. Water yield is the streamflow at the outlet of the watershed expressed as depth of water $(\mathrm{mm})$.

Observed and simulated results were compared by means of the correlation coefficients, the root mean square error (RMSE), and the Nash-Sutcliffe model efficiency (Nash and Sutcliffe, 1970), which estimates the agreement between the 1:1 line and the observed vs. simulated points. The correlation coefficient depicts the strength of the relationship between the observed and predicted values, indicating if both variables varied together or separately. The Nash Sutcliffe coefficient indicates the accuracy of the model in predicting reality. The residuals were calculated as the difference between observed and predicted values. As mentioned previously, some adjustments were made in groundwater inputs to minimize the error and maximize the model efficiency. Other adjustments were also tried, such as changing the evaporation soil correction (ESCO) factor and running the model with different evapotranspiration (ET) methods. ESCO values were varied from 0 to 1, but their effect did not improve the accuracy of the model. When the model was run using the Penman-Monteith and Hargreaves methods to calculate ET, the results did not improve with respect to those for the Priestley-Taylor ET method, and were even slightly poorer.

The final results after calibration for the three watersheds are presented in table 6 . The RMSE slightly decreased and model efficiency increased, especially for monthly streamflow. The highest error in the Harberts watershed could be explained by the distance to the rain gauges, since Harberts was farthest from (and Vernon was closest to) the gauges, which were located at Vernon and Greensburg (fig. 2). Another cause could be the relatively small area of the Harberts watershed (2,411 ha), which makes it more sensitive to input inaccuracies than the Vernon and Deputy watersheds, with areas of 75,886 and 51,281 ha, respectively.

Validation of SWAT-predicted streamflow was carried out for the period January 1995 to September 2002. The results were a little poorer than those for the calibration period. The Harberts watershed again had the largest error, and Vernon had the smallest. The model efficiency was always better for monthly flow than for daily flow. The RMSE and model efficiency for daily and monthly streamflow for the validation period are presented in table 7 . Figures 5 through 7 show

Table 6. RMSE (mm) and Nash-Sutcliffe model efficiency $\left(\mathbf{R}^{2} \mathrm{~N}\right)$ values for streamflow in the calibration period (1980-1994).

\begin{tabular}{|c|c|c|c|c|c|c|}
\hline \multirow[b]{2}{*}{ Watershed } & \multicolumn{2}{|c|}{$\begin{array}{l}\text { RMSE } \\
(\mathrm{mm})\end{array}$} & \multicolumn{2}{|c|}{$\begin{array}{c}\text { Correlation } \\
\text { Coefficient } \\
\text { (R) }\end{array}$} & \multicolumn{2}{|c|}{$\begin{array}{c}\text { Nash-Sutcliffe } \\
\text { Model Efficiency } \\
\left(\mathrm{R}^{2} \mathrm{~N}\right)\end{array}$} \\
\hline & Daily & Monthly & Daily & Monthly & Daily & Monthly \\
\hline Harberts & 3.66 & 27.7 & 0.59 & 0.78 & 0.19 & 0.59 \\
\hline Deputy & 3.53 & 19.8 & 0.47 & 0.85 & -0.23 & 0.73 \\
\hline Vernon & 2.43 & 15.1 & 0.70 & 0.90 & 0.28 & 0.80 \\
\hline
\end{tabular}

Table 7. RMSE (mm) and Nash-Sutcliffe model efficiency $\left(\mathbf{R}^{2} \mathrm{~N}\right)$ values for streamflow for validation period (1995-2002).

\begin{tabular}{|c|c|c|c|c|c|c|}
\hline \multirow[b]{2}{*}{ Watershed } & \multicolumn{2}{|c|}{$\begin{array}{l}\text { RMSE } \\
(\mathrm{mm})\end{array}$} & \multicolumn{2}{|c|}{$\begin{array}{l}\text { Correlation } \\
\text { Coefficient } \\
\text { (R) }\end{array}$} & \multicolumn{2}{|c|}{$\begin{array}{c}\text { Nash-Sutcliffe } \\
\text { Model Efficiency } \\
\left(\mathrm{R}^{2} \mathrm{~N}\right)\end{array}$} \\
\hline & Daily & Monthly & Daily & Monthly & Daily & Monthly \\
\hline Harberts & 5.25 & 38.4 & 0.52 & 0.70 & 0.05 & 0.49 \\
\hline Deputy & 4.26 & 27.6 & 0.54 & 0.78 & -0.35 & 0.61 \\
\hline Vernon & 3.10 & 19.1 & 0.74 & 0.91 & 0.48 & 0.81 \\
\hline
\end{tabular}




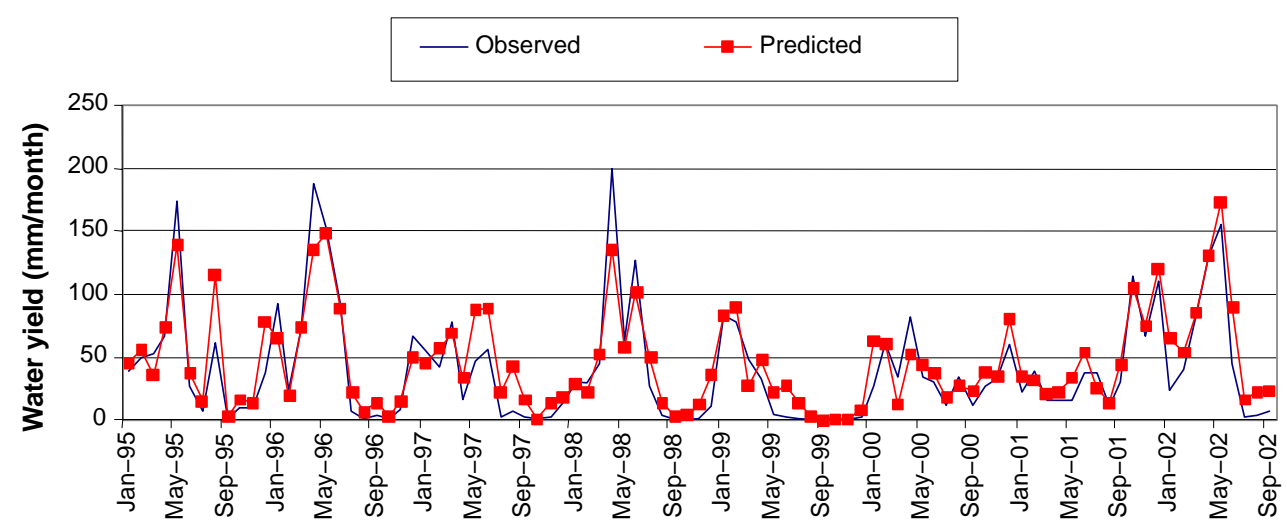

Figure 5.Observed and predicted streamflow for the validation period for the Vernon watershed.

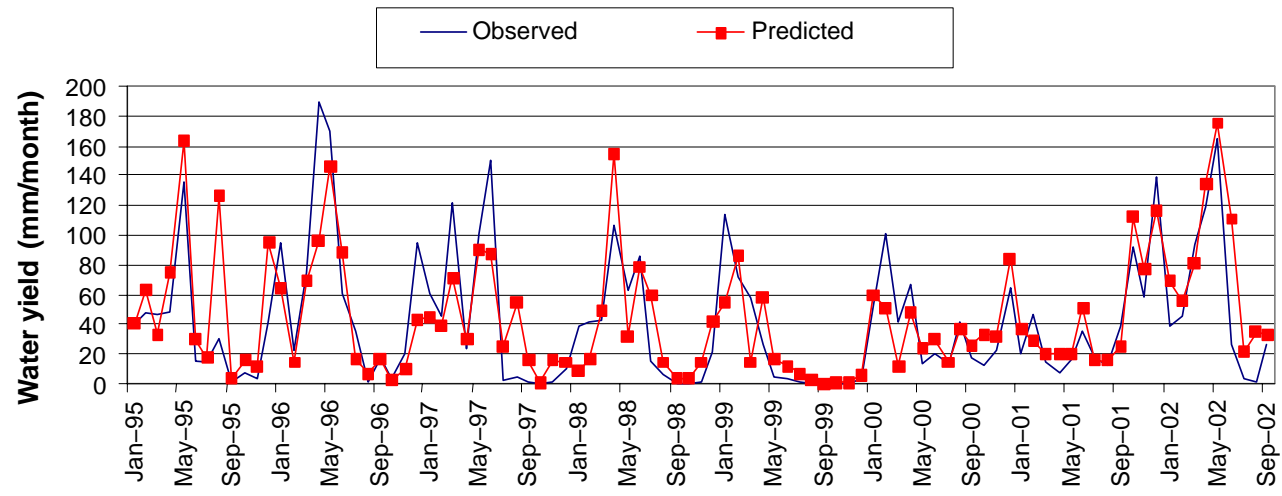

Figure 6. Observed and predicted streamflow for the validation period for the Deputy watershed.

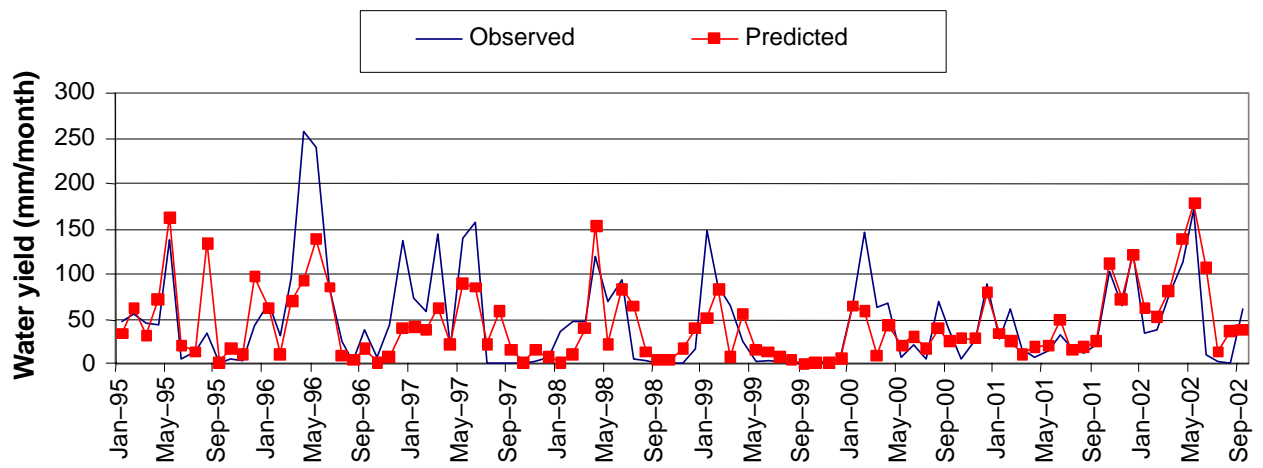

Figure 7. Observed and predicted streamflow for the validation period for the Harberts Creek watershed.

the predicted and observed monthly streamflow for the validation period.

Model efficiency values were similar to those found by Saleh et al. (2000) using SWAT for monthly streamflow on 11 stream sites of the upper North Bosque River watershed in Texas, which ranged between 0.65 and 0.99 . Spruill et al. (2000) also found similar model efficiencies using SWAT, which varied between -0.14 and 0.19 for daily streamflow, and between 0.58 and 0.89 for monthly total flow.

Observing figures 5 through 7, it seems that SWAT might have underestimated the streamflow in some months and overestimated it in other months, which might constitute a systematic error of the model. If so, there should be a common and defined pattern of the monthly residuals over the year, which means that the residuals would be autocorrelated over time. To analyze the time dependency of the residuals, they were considered as time series, and the lag-autocorrelation coefficients were computed for each watershed and plotted in correlograms, which are not presented for economy of the presentation. In all cases, the correlograms showed that the residuals were not correlated, and the lag-correlation coefficients were almost completely included within the $95 \%$ confidence limits for zero correlation (Vazquez-Amábile, 2004). The independency of the residuals was also evaluated using the Porte Manteau lack-of-fit test (Salas et al., 1997) in order to confirm the information provided by the autocorrelation coefficients. The results of the Porte Manteau test confirmed that the residuals were not autocorrelated. Therefore, there was no monthly or seasonal systematic error of the model (Vazquez Amábile, 2004). Thus, overestimation and underestimation of monthly streamflow were not associated with particular months. 


\section{Groundwater Table Depth Calibration and VALIDATION}

Daily and monthly groundwater table depth was calculated and compared with data recorded by Jenkinson (1998) at the Muscatatuck Wildlife Refuge between January of 1992 and December of 1997 for the three soil series (Avonburg, Rossmoyne, and Cobbsfork). The data recorded between 1992 and 1994 were used for the model calibration, and data for the period 1995-1997 were used for model validation. Calibration was carried out by varying the bulk density layer by layer in a range of $\pm 10 \%$. When this variation was not enough, available water content (AWC) was changed within a range of $\pm 10 \%$. Bulk density variation had an effect on the soil porosity and then on the drainage porosity. Varying these soil parameters, the drainage volume-water table depth curve was modified in the three soils. Figure 8 shows the original and calibrated curves for the three soils series.

Once the soils were calibrated for the period 1992-1994, SWAT was run for the period 1995-1996 to validate the model. The RMSE and $\mathrm{R}^{2} \mathrm{~N}$ values were computed by comparing the observed data with the simulated data. The
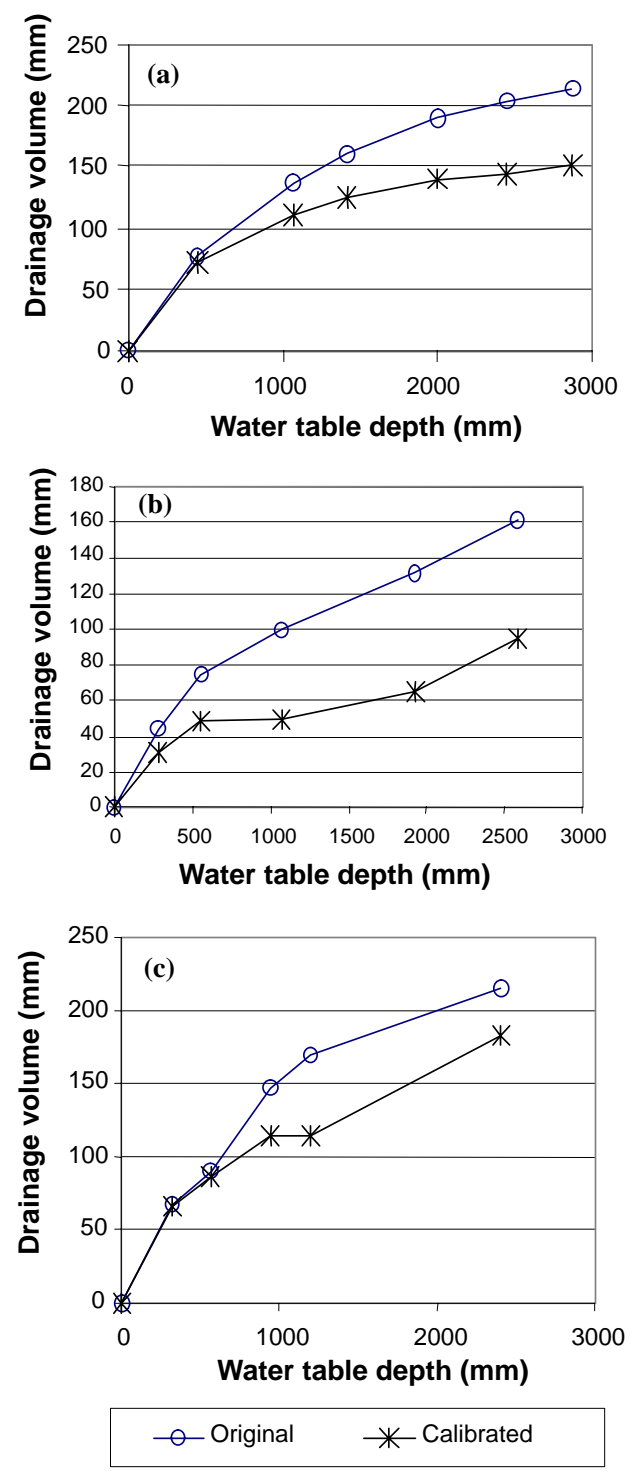

Figure 8. Original and calibrated drainage volume -water table curves for the (a) Avonburg, (b) Cobbsfork, and (c) Rossmoyne series. data were compared using the daily measurements and by grouping the daily observations to create monthly observations. The results are shown in tables 6 and 7 and figures 9 through 11.

When the measurements were grouped by month, the RMSE decreased and the Nash-Sutcliffe efficiency coefficient $\left(\mathrm{R}^{2} \mathrm{~N}\right)$ increased. So, SWAT was again more efficient for monthly estimation than for daily estimation. Event though SWAT presented RMSE from 42 to $84 \mathrm{~cm}$ for monthly estimations, the model was able to predict the groundwater table oscillation over time. This is shown by figures 9 through 11 and by the correlation coefficients (R) in tables 8 and 9 . The correlation coefficients indicate the correlation between the observed and the SWAT-predicted daily and monthly groundwater table depths throughout the calibration and validation periods. The $R$ values varied from 0.46 to 0.82 for daily estimation and from 0.45 to 0.88 for monthly estimation. The magnitude of the correlation coefficient indicates the strength of the relationship between the observed and predicted data, in terms of whether they change together or separately, and the Nash Sutcliffe coefficient explains how far all model predictions were from reality.

The differences between the observed and predicted values can be explained by the variability of soil properties, such as bulk density and available water content (AWC). The model was very sensitive to adjustments in AWC and bulk density when groundwater table depth was calibrated. The soil data were taken from NRCS reports (NRCS, 1976, 1990) because in situ soil measurements were not available. Thus, even though the three soils were classified in situ as Avonburg, Rossmoyne, and Cobbsfork, NRCS soil data represent a mode profile and may not represent the properties of the series at the observation wells, and this could be a source of error in the model calibration. Amatya et al. (2003) found that DRAINMOD performed poorly in predicting groundwater table depth during two years when the model was not calibrated using in situ soil measurements.

It was also difficult to determine a unique cause for the errors because there was no common pattern in the error for the three soils. In Avonburg, the groundwater table was mostly underestimated, but fairly well predicted. In Cobbsfork, it was under- and overestimated, and in Rossmoyne, it was mostly overestimated. Over- and underestimations by the model were not associated with any season, so the error did not seem to be associated with a deficiency in the computation of the evapotranspiration. These differences between predicted and observed data could be due to several sources of uncertainty, such as inaccurate soil data, lack of in situ precipitation records, and the assumptions of the estimated drainage volume-water table curve.

SWAT predicted the groundwater table with an average RMSE of $55 \mathrm{~cm}$ for the calibration period and $76 \mathrm{~cm}$ for the validation period (tables 8 and 9). These results were acceptable, considering the simplicity of the SWAT soil water balance with respect to other models like DRAINMOD, which simulates unsaturated flow using sub-daily weather data. DRAINMOD simulations conducted for silt loam and loam soils of Iowa predicted water table elevations within an average deviation of 15 and $19 \mathrm{~cm}$, respectively (Sanoja et al., 1990). Similarly, Madramootoo et al. (1999) reported that DRAINMOD-N predicted the groundwater table depth with a standard error of 16 to $21 \mathrm{~cm}$ in eastern Canada. 


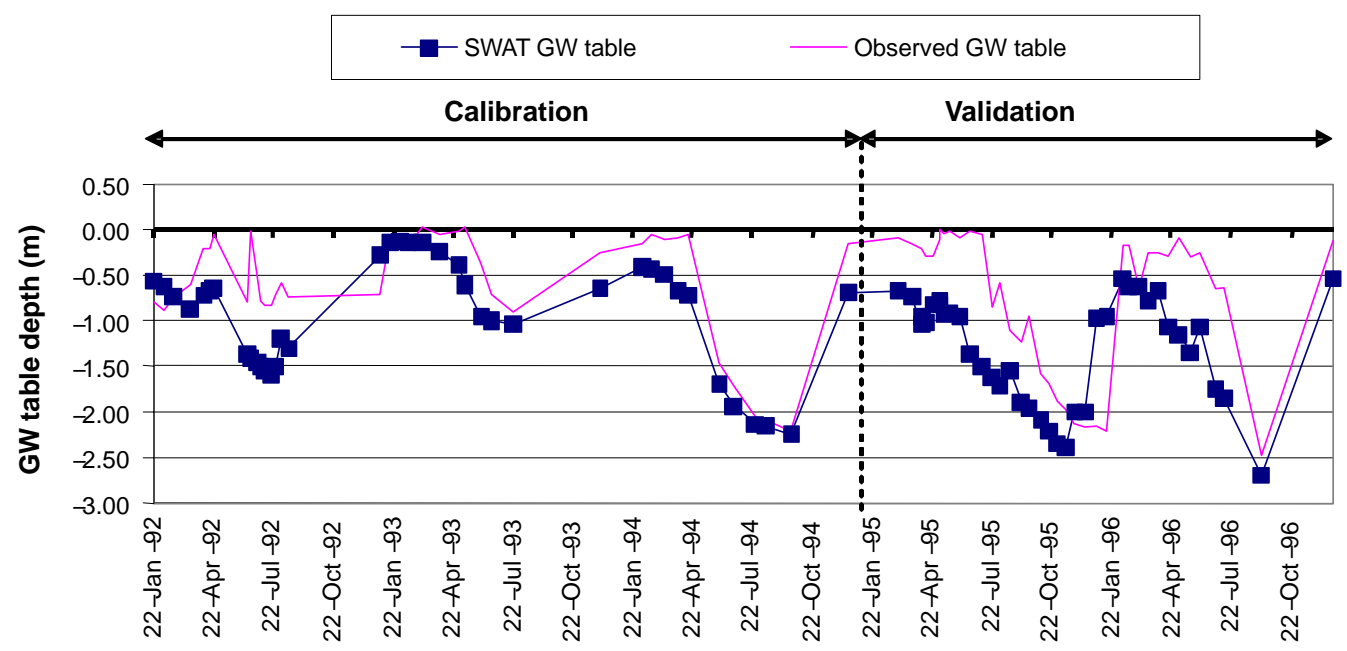

Figure 9. Observed and simulated data for the calibration and validation periods for the observation well located on the Avonburg soil.

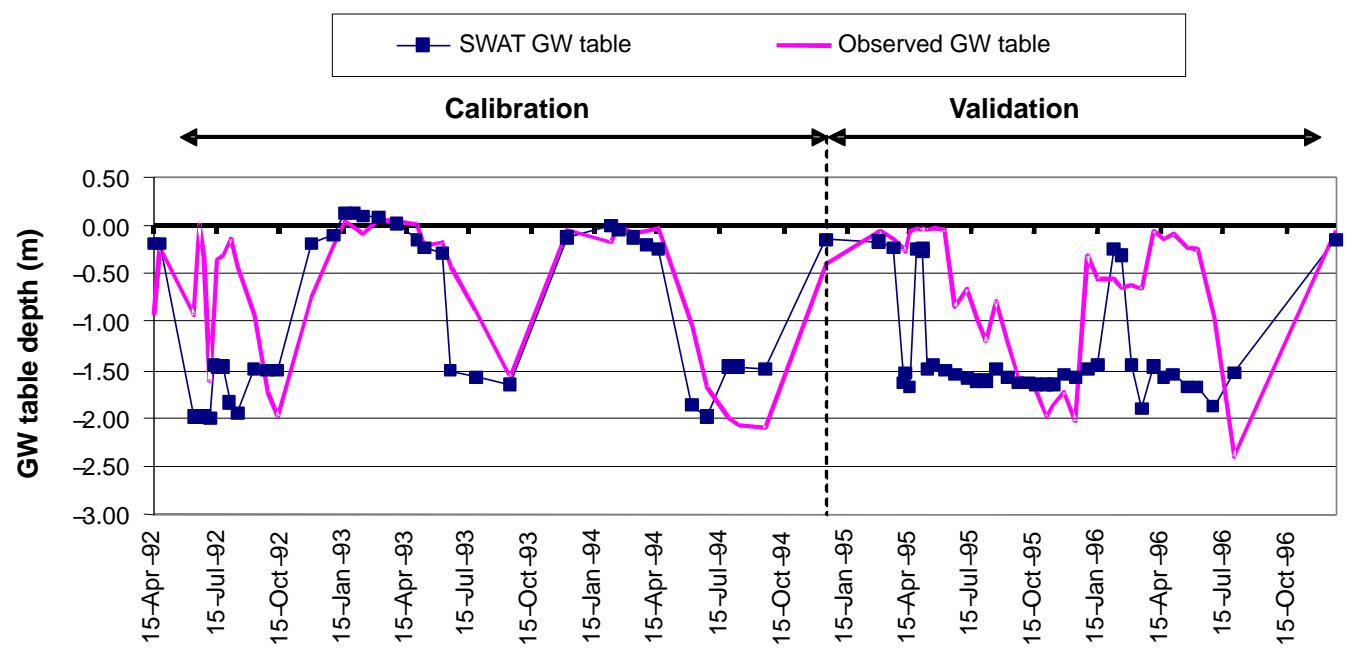

Figure 10. Observed and simulated data for the calibration and validation periods for the observation well located on the Cobbsfork soil.

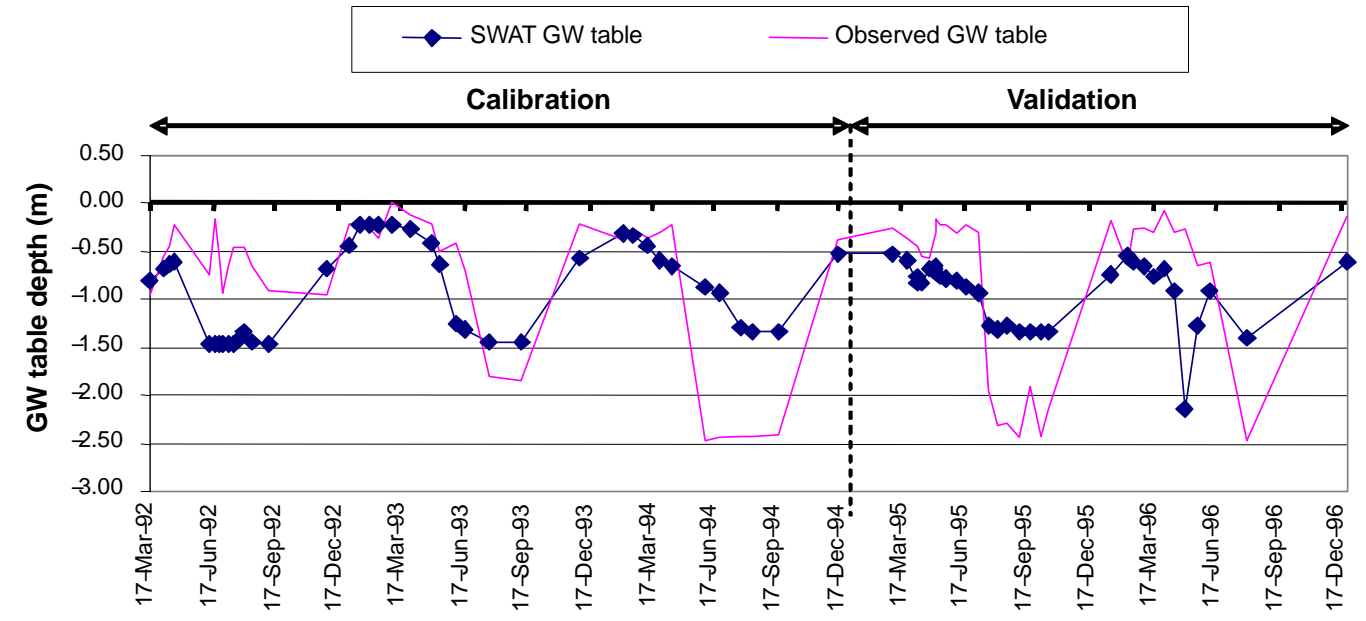

Figure 11. Observed and simulated data for the calibration and validation periods for the observation well located on the Rossmoyne soil. 
Table 8. RMSE and Nash-Sutcliffe model efficiency for groundwater table depth for calibration period (1992-1994).

\begin{tabular}{|c|c|c|c|c|c|c|}
\hline & \multicolumn{3}{|c|}{ Daily } & \multicolumn{3}{|c|}{ Monthly } \\
\hline & $\begin{array}{c}\text { RMSE } \\
(\mathrm{m})\end{array}$ & $\begin{array}{l}\text { Nash-Sutcliffe } \\
\text { Model Efficiency } \\
\left(\mathrm{R}^{2} \mathrm{~N}\right)\end{array}$ & $\begin{array}{l}\text { Correlation } \\
\text { Coefficient } \\
\text { (R) }\end{array}$ & $\begin{array}{c}\text { RMSE } \\
(\mathrm{m})\end{array}$ & $\begin{array}{l}\text { Nash-Sutcliffe } \\
\text { Model Efficiency } \\
\left(\mathrm{R}^{2} \mathrm{~N}\right)\end{array}$ & $\begin{array}{l}\text { Correlation } \\
\text { Coefficient } \\
\text { (R) }\end{array}$ \\
\hline Avonburg & 0.51 & 0.28 & 0.82 & 0.42 & 0.61 & 0.88 \\
\hline Cobbsfork & 0.74 & -0.12 & 0.60 & 0.59 & 0.36 & 0.71 \\
\hline Rossmoyne & 0.69 & 0.15 & 0.46 & 0.65 & 0.40 & 0.64 \\
\hline
\end{tabular}

Table 9. RMSE and Nash-Sutcliffe model efficiency for groundwater table depth for validation (1995-1996).

\begin{tabular}{|c|c|c|c|c|c|c|}
\hline & \multicolumn{3}{|c|}{ Daily } & \multicolumn{3}{|c|}{ Monthly } \\
\hline & $\begin{array}{l}\text { RMSE } \\
(\mathrm{m})\end{array}$ & $\begin{array}{l}\text { Nash-Sutcliffe } \\
\text { Model Efficiency } \\
\left(\mathrm{R}^{2} \mathrm{~N}\right)\end{array}$ & $\begin{array}{l}\text { Correlation } \\
\text { Coefficient } \\
\text { (R) }\end{array}$ & $\begin{array}{l}\text { RMSE } \\
(\mathrm{m})\end{array}$ & $\begin{array}{l}\text { Nash-Sutcliffe } \\
\text { Model Efficiency } \\
\left(\mathrm{R}^{2} \mathrm{~N}\right)\end{array}$ & $\begin{array}{l}\text { Correlation } \\
\text { Coefficient } \\
\text { (R) }\end{array}$ \\
\hline Avonburg & 0.80 & -0.05 & 0.71 & 0.79 & 0.10 & 0.68 \\
\hline Cobbsfork & 0.92 & -0.74 & 0.41 & 0.84 & -0.51 & 0.45 \\
\hline Rossmoyne & 0.69 & 0.33 & 0.63 & 0.65 & 0.38 & 0.67 \\
\hline
\end{tabular}

\section{CONCLUSIONS AND RECOMMENDATIONS FOR FUTURE RESEARCH}

The SWAT model was calibrated and validated for streamflow for three watersheds in the Muscatatuck River basin in southeast Indiana. The streamflow predictions of the model were acceptable for monthly time intervals, but the model performed somewhat poorly in predicting daily streamflow. The Nash-Sutcliffe model efficiency $\left(\mathrm{R}^{2} \mathrm{~N}\right)$ for monthly streamflow was $0.49,0.61$, and 0.81 for the three watersheds in the validation period (1995-2002), similar to those found in the literature. The better predictions were for the Vernon and Deputy watersheds, which were nearest the weather station and also the largest watersheds.

A procedure to compute the water table depth of a shallow aquifer using the soil input data and the SWAT output "daily soil water content by layer" was proposed based on the theory used by DRAINMOD. This procedure allowed prediction of shallow aquifer oscillations between the soil surface and the lower limit of the soil bottom layer. Thus, groundwater table depth was computed daily for each soil based on the relationship of water table depth and drainage volume. The model efficiency $\left(\mathrm{R}^{2} \mathrm{~N}\right)$ for monthly groundwater table depth was $0.61,0.36$, and 0.40 for the three wells in the calibration period, and $0.10,-0.51$, and 0.38 for the validation period. The performance of the model in predicting groundwater table depth was not as good as for streamflow. However, the model was able to predict the seasonal variation of the groundwater table, with correlation coefficients that varied from 0.46 to 0.88 in the calibration period and from 0.41 to 0.71 in the validation period. Inaccurate soil data, lack of in situ precipitation records, and the assumptions of the estimated drainage volume-water table curve were identified as the main sources of error in predicting the groundwater table. Another potential source of error is the contribution of the surrounding soil units to the groundwater table depth. This might be solved through the spatial discretization of the HRUs, which would allow the computation of the interaction of the soil units within every subbasin by lateral flow from units located upstream.

Based to these results, the prediction of groundwater table depth based on daily soil water content might be an interesting capability for inclusion in SWAT, which would compute this variable for all soils of a watershed without using sub-daily precipitation data and soil retention curves.
Furthermore, it makes it possible to analyze the impact of different scenarios, such as land use changes, weather change, or management practices, on the variation of the shallow aquifer at different points of a basin. However, further studies using additional data, along with in situ precipitation and soil measurements, are recommended to better analyze the performance of SWAT in predicting this variable. A good understanding of the prediction of groundwater table depth by SWAT would be useful in the study of the performance of the model's soil water balance.

\section{ACKNOWLEDGEMENTS}

We wish to acknowledge the financial support of theBunge \& Born Foundation, Fulbright Commission-Argentina.We are also very grateful to Jeff Arnold and Nancy Sammons from the SWAT team at Texas A\&M University; Larry Theller, Kelsi Bracmort, and Ravi Narayan from the ABE Department at Purdue University; Albert Rutledge from USGS; and Byron Jenkinson and Ken Scheringa from the Agronomy Department and Dr. Ramachandra Rao from the Civil Engineering Department at Purdue University for their collaboration on this project.

\section{REFERENCES}

Amatya, D. M., G. Sun, R. W. Skaggs, and C. C. Trettin. 2003. Testing of DRAINMOD for forested watersheds with non-pattern drainage. ASAE Paper No. 032046. St. Joseph, Mich.: ASAE.

Ambroise, B., K. Beven, and J. Freer. 1996. Toward a generalization of the TOPMODEL concepts: Topographic indices of hydrological similarity. Water Resources Research 32(7): 2135-2145.

Arnold, J. G., and P. M. Allen. 1996. Estimating hydrologic budgets for three Illinois watersheds. J. Hydrology 176: 57-77.

Arnold, J. G., R. Srinavasan, R. S. Muttiah, and J. R. Williams. 1998. Large-area hydrologic modeling and assessment: Part I. Model development. J. American Water Resources Assoc. 34(1): 73-89.

Ascough, J. C., C. Baffaut, M. A. Nearing, and B. Y. Liu. 1997. The WEPP watershed model: I. Hydrology and erosion. Trans. ASAE 40(4): 921-933.

Beven, K. 1984. Infiltration into a class of vertically non-uniform soils. Hydrological Sci. J. 29(4): 425-434.

Bicknell, B. R., J. C. Imhoff, J. L. Kittle, Jr., and A. S. Donigian Jr. 1996. Hydrological Simulation Program - Fortran: User's 
manual for release -11. Athens, Ga.: U.S. EPA Office of Research and Development, Environmental Research Laboratory.

Brown, L. C., and T. O. Barnwell. 1987. The enhanced stream water quality models QUAL2E and QUAL2E-UNCAS: Documentation and user manual. EPA/600/3-87/007. Athens, Ga.: U.S. EPA Office of Research and Development, Environmental Research Laboratory.

Charbeneau, R. J. 2000. Groundwater Hydraulics and Pollutant Transport. Upper Saddle River, N.J.: Prentice Hall.

Changnon, S. A. 1996. The Great Flood of 1993: Causes, Impacts, and Responses. Boulder, Colo.: Westview Press.

Dillaha, T. A., M. L. Wolfe, A. Shirmohammadi, and F. W. Byne. 1998. ANSWERS-2000. ASAE Paper No. 982199. St. Joseph, Mich.: ASAE.

Di Luzio M., R. Srinavasan, and J. G. Arnold. 2001. ArcView Interface for SWAT2000: User's Guide. Temple, Texas: Blackland Research Center, Texas Agricultural Experiment Station. Available at: www.brc.tamus.edu/swat/swatdoc.html.

Haan, C. T., B. J. Barfield, and J. C. Hayes. 1994. Design Hydrology and Sedimentology for Small Catchments. San Diego, Cal.: Academic Press.

Jenkinson, B. J. 1998. Wet soil monitoring project on two till plains in south and west central Indiana. MS thesis. West Lafayette, Ind.: Purdue University.

Johnson, A. I. 1967. Specific yield: Compilation of specific yields for various materials. Water Supply Paper 1662-D. Washington, D.C.: U.S. Geological Survey.

Knisel, W. G. 1980. CREAMS, a field-scale model for chemicals, runoff, and erosion from agricultural management systems. Conservation Research Report No. 26. Washington, D.C.: USDA.

Leonard, R. A., W. G. Knisel, and D. A. Still. 1987. GLEAMS: Groundwater loading effects on agricultural management systems. Trans. ASAE 30(5): 1403-1428.

Madramootoo, C. A., J. W. Kaluli, and G. T. Dodds. 1999. Simulating nitrogen dynamics under water table management systems with DRAINMOD-N. Trans. ASAE 42(4): 965-973.

Miller, E. W., and R. M. Miller. 2000. Natural Disasters: Floods: A Reference Handbook. Santa Barbara, Cal.: ABC-CLIO.

Nash, J. E., and J. E. Sutcliffe. 1970. River flow forecasting through conceptual models: Part 1. A discussion of principles. $J$. Hydrology 10(3): 282-290.

Neitsch, S. L., J. G. Arnold, J. R. Kiniry, and J. R. Williams. 2001. Soil and Water Assessment Tool: Theoretical documentation, version 2000. Temple, Texas: Blackland Research Center, Texas Agricultural Experiment Station. Available at: www.brc.tamus.edu/swat/swatdoc.html.
NRCS. 1976. Soil survey of Jennings County, Indiana. Washington, D.C.: USDA Soil Conservation Service.

NRCS. 1990. Soil survey of Jackson County, Indiana. Washington, D.C.: USDA Soil Conservation Service.

Pivot, J. M., E. Josien, and P. Martin. 2002. Farms adaptation to changes in flood risk: A management approach. J. Hydrology 267(1-2): 12-25.

Refshaard, J. C., B. Storm, and V. P. Singh. 1995. MIKE-SHE. In Computer-Models of Watershed Hydrology, 809-846. Littleton, Colo.: Water Resources Publications.

Rutledge, A. T. 1993. Computer programs for describing the recession of groundwater discharge and for estimating mean groundwater recharge and discharge from streamflow records. USGS Water Resources Investigations Report 93-4121. Washington, D.C.: U.S. Geological Survey.

Salas, J. D., J. W. Delleur, V. Yevjevich, and W. L. Lane. 1997. Applied Modeling of Hydrologic Time Series. 4th ed. Littleton, Colo.: Water Resources Publications.

Saleh A., J. G. Arnold, P. W. Gassman, L. M. Hauck, W. D. Rosenthal, J. R. Williams, and A. M. S. McFarland. 2000. Application of SWAT for the upper North Bosque River watershed. Trans. ASAE 43(5): 1077-1087.

Sanoja, J., R. S. Kanwar, and S. W. Melvin. 1990. Comparison of simulated (DRAINMOD) and measured tile outflow and water table elevations from two field sites in Iowa. Trans. ASAE 33(3): 827-833.

Skaggs, R. W. 1980. DRAINMOD reference report. Washington, D.C.: USDA Soil Conservation Service.

Spruill, C. A., S. R. Workman, and J. L. Taraba. 2000. Simulation of daily and monthly stream discharge from small watersheds using the SWAT model. Trans. ASAE 43(6): 1431-1439.

USGS. 2003a. NWISWeb data for the nation. Available at: http://waterdata.usgs.gov/nwis. Accessed 20 May 2003.

USGS. 2003b. Groundwater information pages. Available at: http://waterusgs.gov/ogw/gwsw.html. Accessed 15 Jun 2003.

Vazquez-Amábile, G. 2004. Computation of groundwater table depth and flood risk on farm fields using SWAT. MS thesis. West Lafayette, Ind.: Purdue University.

Williams, J. R., C. A. Jones, and P. T. Dyke. 1984. A modeling approach to determining the relationship between erosion and soil productivity. Trans. ASAE 27(1): 129-144.

Williams, J. R., A. D. Nicks, and J. G. Arnold. 1985. Simulator for water resources in rural basins. J. Hydraulic Eng. 111(6): 970-986. 